\title{
Civic Promoters of Celestial Protectors: The Arca di San Donato at Arezzo and the Crisis of the Saint's Tomb around 1400
}

\author{
ULRICH PFISTERER
}

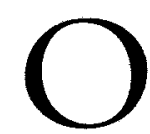
n 15 March 1478, Giovanni Antonio Piatti, the Milanese sculptor acclaimed as the new Praxiteles, Polykleitos, and Phidias of his time, ${ }^{1}$ was commissioned by the abbot of the Benedictine monastery of San Lorenzo in Cremona to design and construct a new marble shrine for the monks' prized relics - the bones of the four 'Holy Persian Martyrs'. The contract specified that the shrine was to be made

eiusdem bonitatis et in ita laudabili forma, in ea de qua sunt figure sculpte ad Archas Sanctorum Augustini confessoris in Castro Civitatis Papie, et Sancti Petri Martiris in Civitate Mediolani et Sancti Dominici in Civitate Bononie

that is, on the model of the tombs of Saint Augustine in Pavia, Saint Peter Martyr in Milan, and Saint Dominic in Bologna (commonly known as the Arca di San Domenico).$^{2}$ Indeed, it was not uncommon for fifteenth-century contracts to refer to works already in existence as a sort of quality control. In Piatti's case, however, the sculptor was required to follow a group of examples, the oldest of which-the 1267 Arca di San Domenico-had been completed more than two centuries earlier. This unusual retrospection resulted from the distinctive status of the model in question: Nicola Pisano's Arca di San Domenico was known to have introduced a new type of saint's tomb, one raised on columns and ornamented with reliefs showing scenes from the saint's life. ${ }^{3}$ Over the next two centuries, this form became somewhat of a template, a standard invested with tradition and meaning. Piatti's return to it, in fact, seems to continue a tendency already evident in the fourteenth century. We know, for instance, that the decision of the Dominican general chapter of 1335 to erect a new tomb for Saint Peter Martyr also insisted that its artist base his work on the Arca di San Domenico. ${ }^{4}$ The result, signed and dated 1339 by the Pisan sculptor Giovanni di Balduccio, seems not merely to imitate, but to improve upon and even outdo the prototype. This might remind us of the precise demands made in the contract for the Persian Martyrs: 'potius melioris bonitatis quam deterioris'. And what is true for these two examples also seems to be true for countless others. All pursued a strategy of emulation, a strategy motivated most often by competition between orders, cities, or donors. ${ }^{5}$

It might be said that Piatti's strategy was itself anticipated in the Arca di San Domenico for it was not only the imitator who, in the eyes of his contemporaries, rivalled ancient sculptors. Pisano's arca itself had been compared with ancient Roman triumphal arches and commemorative columns. ${ }^{6}$ His innovative design for a saint's tomb, with its supporting columns and narrative reliefs, was understood from the outset as a revisitation, or an updated interpre-tation, of ancient Classical monuments-that is to say, a triumphant Christian memorial for a saint. Significantly, the burial of saints in ancient sarcophagi, previously a frequent practice in the Middle Ages, virtually came to an end with the appearance of this new tomb type in 1267.7

Together, tombs like those by Piatti and Balduccio, among others, illustrate what seems to 


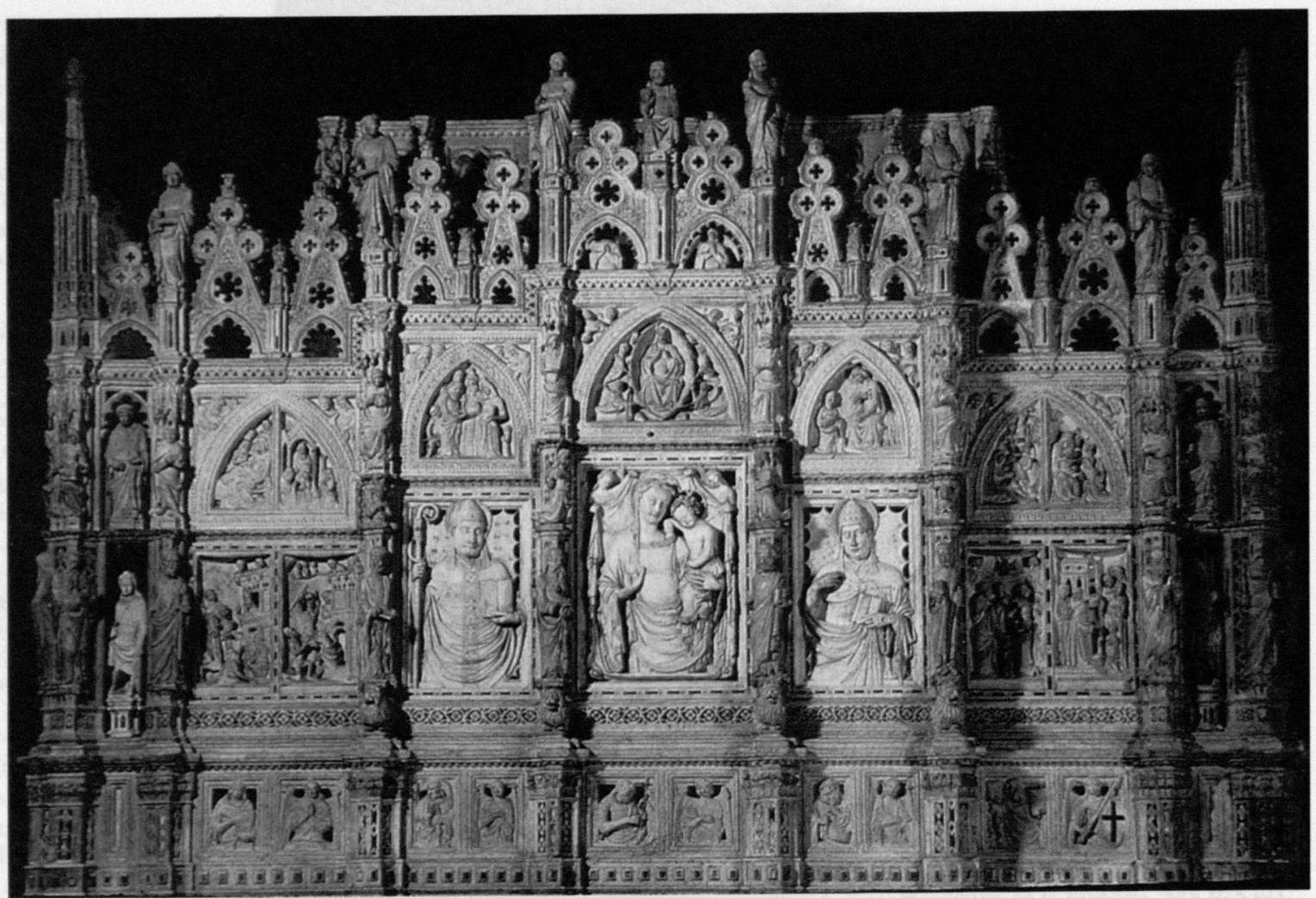

Fig. 1. Arca di San Donato, front. Arezzo, cathedral, after 1362-c. 1375 (photo: Kunsthistorisches Institut in Florence)

be a continuous development in the design of saints' tombs from the appearance of the Arca di San Domenico to the beginning of the Reformation in the early sixteenth centuryall, directly or indirectly, in response to Nicola Pisano's archetype. ${ }^{8}$ The impression of 'emulative continuity', however, does not tell the complete story: there is also a striking and previously unexplained interruption in this series of monuments. A survey, undertaken here for the first time, of 94 tombs erected in northern and central Italy between 1267 and $c$. $1524 / 25$ reveals that some 36 monuments originated in the first 120 years of this period, and another 53 in the last 80 years (see Appendix). In the 50 to 60 year interval, however (that is, from c. 1380 to $1430 / 40$ ) a crisis in the development of the saint's tomb seems to have occurred. In these years, with five (mostly provincial) exceptions, ${ }^{9}$ all those funerary monuments that do appear are 'simple' tomb forms - wooden sarcophagi, frescoed epitaphs, or plain slabs. ${ }^{10}$ Even allowing a margin of error for the statistics (later renovations often destroyed all traces of numerous tombs, and I surely have not catalogued every example), the hiatus around 1400 remains to be explained.

The aim of this article is twofold: first, to discuss one of the last and greatest of the saints' monuments that appeared before the onset of this 'crisis', the Arca di San Donato, begun after 1362 in Arezzo Cathedral; second, to examine more closely the interruption in the construction of saints' tombs that occurred between $c$. 1380 and $1430 / 40$.

\section{The Arca di San Donato in Arezzo}

When the Aretines completed the reconstruction of their cathedral in the late thirteenth century, they reserved the place of honour, the space behind the altar, for the shrine containing the body of Saint Donatus (figs 1-3). ${ }^{11}$ Donatus, the second Bishop of Arezzo, who was martyred according to legend in 362 , had become the city's patron saint. ${ }^{12}$ His tomb-monument was built in two phases. The actual altar block, with its blind arcade of pointed arches and figures of saints on the reverse, should probably be dated around 1289 , since, by this date, masses were already being celebrated in the 


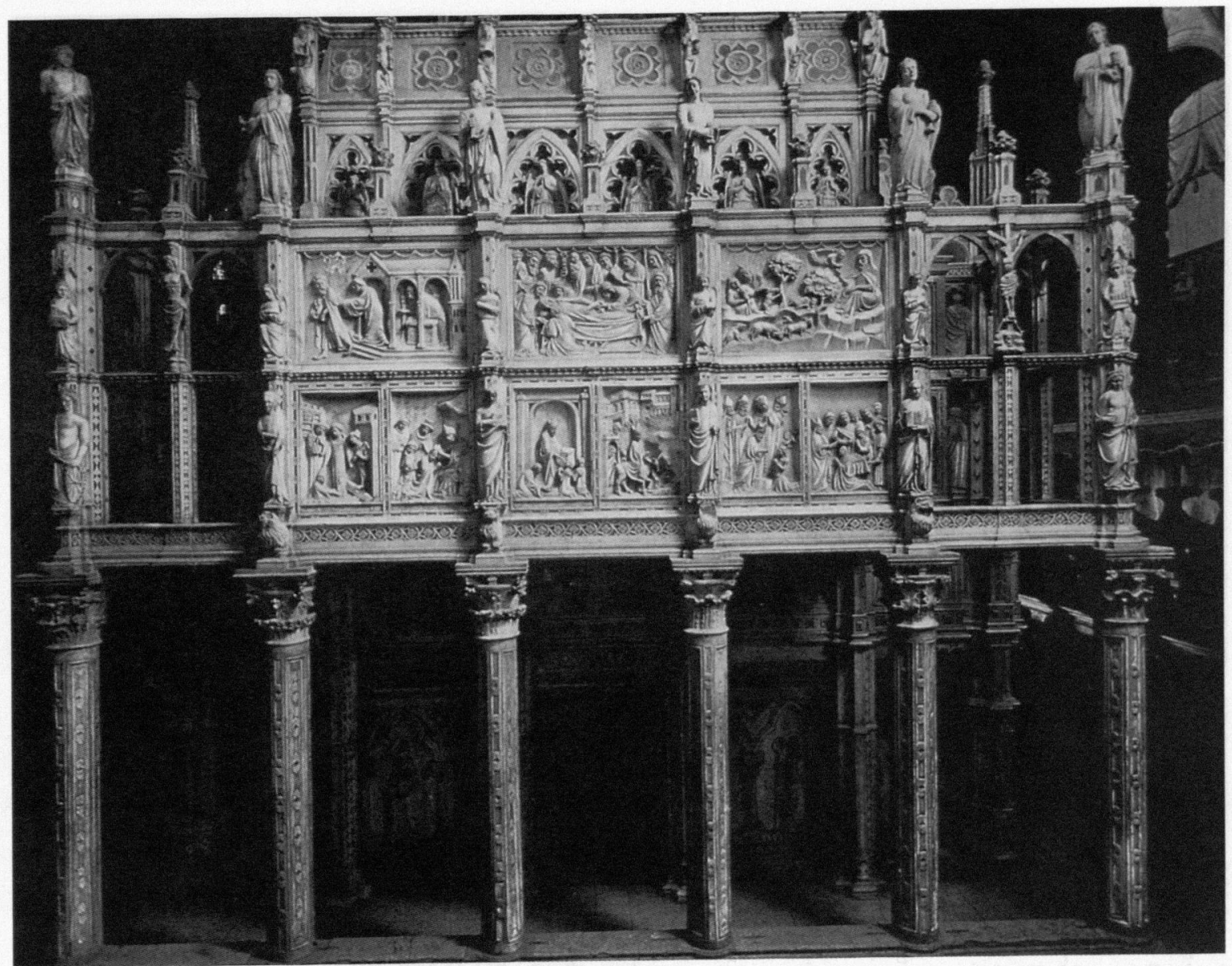

Fig. 2. Arca di San Donato, rear. Arezzo, cathedral, after 1362-c. 1375 (photo: Kunsthistorisches Institut in Florence)

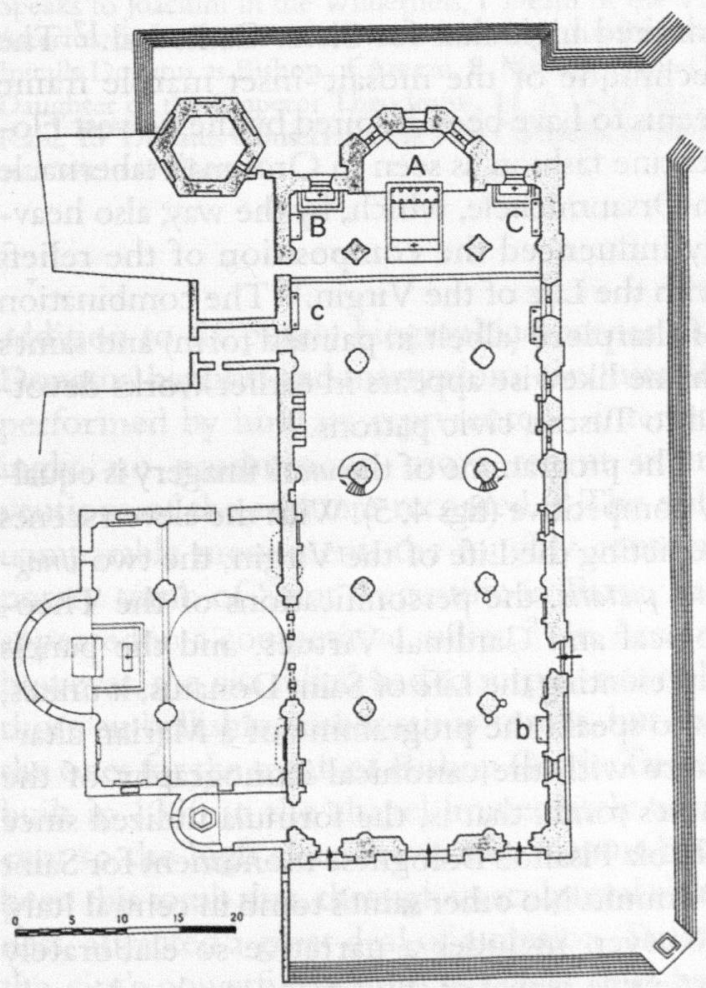

cathedral's presbytery. ${ }^{13}$ The original cult seems to have required an open passage behind the altar, as its construction indicates. On either side of this space, two rows of saints were arranged: Saints Peter, Donatus, and Lucilla (?) to the right; and Saints Paul, Gregory X, and Flora (?) to the left. The faithful must have, in all likelihood, approached the back of the altar on their knees, that is, with the small statues of saints at eye-level, in order to view and contemplate the relics found there. ${ }^{14}$

After 1362, this altar block was covered with a hybrid structure that superimposed an altarpiece upon a reliquary shrine. Of the group of

Fig. 3. Ground plan of Arezzo Cathedral, indicating the locations for the Arca di San Donato (A) and the tombs of Pope Gregory X (B: original location, b: location after 1810) and Bishop Guido Tarlati (C: original location, c: location after the late eighteenth century) (drawing: author and Michael Pfisterer) 


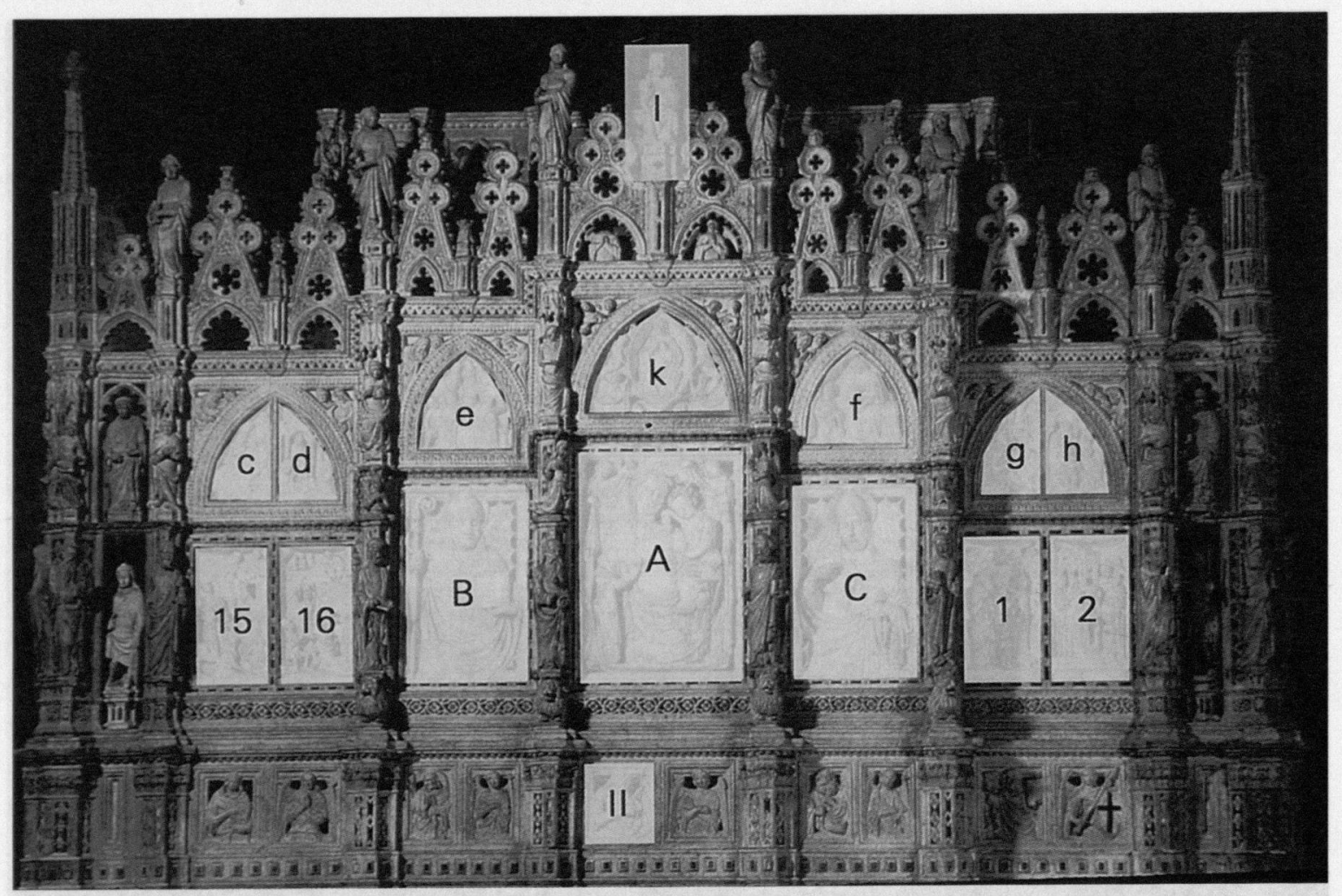

Fig. 4. Iconographic scheme of the Arca di San Donato, front.

A Madonna and Child, B St Donatus, C St Gregory X, I Blessing Christ, II Saint John the Baptist, c Birth of the Virgin, d Presentation of the Virgin in the Temple, e Marriage of the Virgin, $\mathbf{f}$ Annunciation, $\mathbf{g}$ Nativity, $\mathbf{h}$ Adoration of the Magi, k Assumption of the Virgin, 1 Baptism of Donatus, 2 Donatus Meets the Monk Hilarius, 15 Donatus Preaching in the Prison, 16 Decapitation of Donatus (graphics: author and Michael Pfisterer)

sculptors who executed this, the names of Giovanni di Francesco da Arezzo and Betto di Francesco da Firenze are recorded. ${ }^{15}$ Unfortunately, the sources give no further information about this alteration, so that a discussion about it must rely on visual evidence alone. Noting the numerous ways in which strategies of emulation are pursued best elucidates this evidence. The tomb in Arezzo aimed not only to exceed every comparable saint's tomb in the area, but also-through its sculptural richness, opulent ornament, and distinctive iconography-to compete with the increasingly popular, ever more magnificent lay tombs. Some of these were also being erected behind high altars, even as free-standing monuments on supports emulating a typology formerly reserved for saints. ${ }^{16}$ Of special note is the front side of the altarretable, which shows the Madonna and Child flanked by the civic patrons Donatus and Gregory; it utilizes a support apparatus adopted from the so-called buttressed altarpiece, a form most likely introduced first by Duccio in his much admired high altar for Siena Cathedral. ${ }^{17}$ The technique of the mosaic-inset marble frame seems to have been inspired by the newest Florentine fashion as seen in Orcagna's tabernacle in Orsanmichele, which, by the way, also heavily influenced the composition of the reliefs with the Life of the Virgin. ${ }^{18}$ The combination of altarpiece (albeit in painted form) and saint's shrine likewise appears in earlier works devoted to Tuscan civic patrons. ${ }^{19}$

The programme of the arca's imagery is equally competitive (figs 4,5 ). With the eleven scenes depicting the Life of the Virgin, the two imagines pietatis, the personifications of the Theological and Cardinal Virtues, and the panels representing the Life of Saint Donatus, it unites, so to speak, the programme of a Marian altarpiece with the canonical iconography of the saint's tomb, that is, the formula utilized since Nicola Pisano's Bolognese monument for Saint Dominic. No other saint's tomb in central Italy, however, includes a narrative so elaborately extensive as that of the Arezzo tomb, where, in 


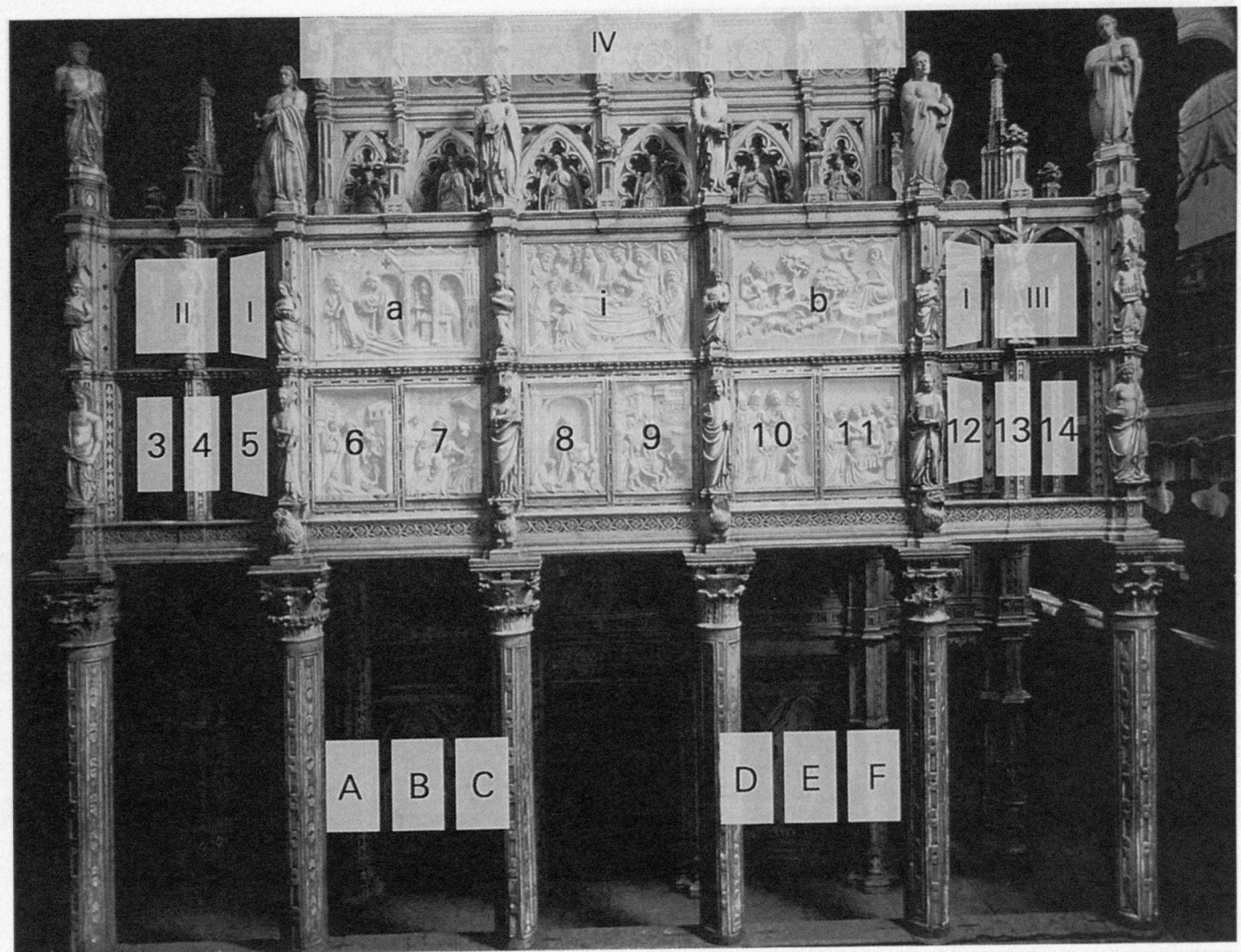

Fig. 5. Iconographic scheme of the Arca di San Donato, rear.

A St Flora (?), B St Gregory X, C St Peter, D St Paul, E St Donatus, F St Lucilla (?), I Imago Pietatis, II Resurrection of Souls at the Last Judgement and Hell, III Resurrection of Christ and Annunciation of the Death of the Virgin, IV Theological / Cardinal Virtue (on the lateral sides: Liberal Arts), a Expulsion of Joachim from the Temple, b An Angel Speaks to Joachim in the Wilderness, $\mathbf{i}$ Death of the Virgin, 3 Donatus Cures the Blind Siranna, 4 Donatus Exorcises Asterius, Son of the Roman Prefect, 5 Donatus Baptizes Siranna, 6 Eufrosina Is Resurrected by Donatus, 7 The Pope Installs Donatus as Bishop of Arezzo, 8 Miracle of the Chalice, 9 Miracle of the Dragon, 10 Donatus Exorcises Antilia, Daughter of the Emperor Theodosius, 11 A Dead Man is Resurrected by Donatus, 12 Donatus Provokes a Miraculous Rain, 13 Donatus Consecrates the First Cathedral of Arezzo, 14 Donatus Is Interrogated by Quadrazianus (graphics: author and Michael Pfisterer)

addition to six purely biographical scenes like Donatus' baptism and martyrdom, ten miracles performed by him are represented - interestingly, no posthumous, more recent interventions of the saint are recorded. ${ }^{20}$ The only comparable monument, the roughly contemporary tomb of Saint Augustine in Pavia, also appeared in a competitive milieu. ${ }^{21}$ In Arezzo, however, the vita reliefs had to surpass not only those embellishing other saints' tombs, but also the ones for the tomb of Bishop Guido Tarlati, built in 1330 in the chapel immediately adjacent to the high altar. Previously, it must have been this tomb that, through its sculptural richness, attracted a great deal of attention. Tarlati, the city's powerful bishop and ruler, had had the most important events in his life portrayed on his tomb in a series of sixteen reliefs, thus creating, simultaneously, a liturgical and secular monument (fig. 6). ${ }^{22}$ Saint Donatus's tomb did not trump this profane, elaborate monument by increasing the number of narrative scenes it included. Instead, by incorporating the many miracle scenes attributed to Saint Donatus, the arca's hagiographic identity underscored the difference between a tomb for the holy dead and a tomb for a non-canonized person. Moreover, it used the arca itself to visualize the Heavenly Jerusalem, thereby implying that the saint was already an inhabitant of the civitas Dei. For contemporary viewers, this association between the arca and the Heavenly Jerusalem would have 


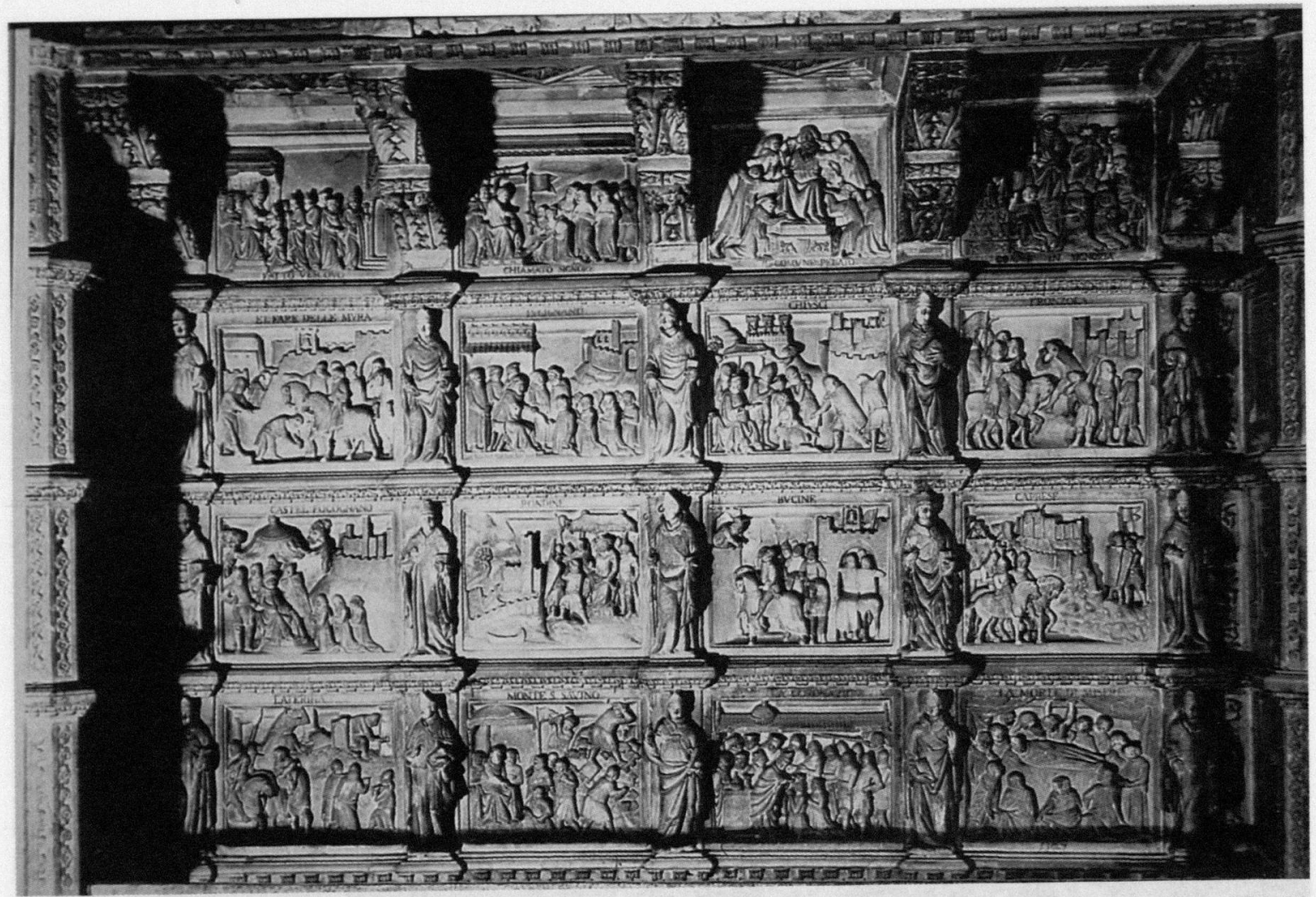

Fig. 6. Agostino di Giovanni and Agnolo di Ventura, tomb of Bishop Guido Tarlati (detail). Arezzo, cathedral, 1327-30 (photo: Kunsthistorisches Institut in Florence)

been a familiar one: a sermon on Saint Donatus by Peter Damian, whose writings on Church reform were well known in the fourteenth and fifteenth centuries, had described the blessed bishop's fervent faith metaphorically as the 'walls of a shining town fortress' and Donatus himself as the 'building block' of a heavenly city. ${ }^{23}$ This traditional characterization of the saints as lapides vivi was, in fact, still widely current by the late Trecento. Petrus de Natalibus, for one, recalled this metaphor explicitly in the introduction to his roughly contemporary Catalogus Sanctorum: "The uncreated Wisdom of the Divine Word [...] built itself the house of the most holy Church $[\ldots]$ not with hewn stones or handmade walls, but rather invisibly, out of the merits of the saints'. ${ }^{24}$ Related to this comparison was another metaphor, the idea that the Heavenly Jerusalem outshone all the marble works and all known mosaics created by the ancients. ${ }^{25}$ This association between the Heavenly Jerusalem and artistic media, in turn, was visually reinforced by the framework of the arca itself, for, like the celestial city, its diminutive architectural border is also surrounded by angels. The relief showing the resurrection of souls at the sound of angels blaring trumpets during the Last Judgment (fig. 7), makes it probable that Peter Damian's sermon influenced the designers of the programme for this tomb. In point of fact, Damian had described the very same musi$\mathrm{cal}$ instruments as heralding Saint Donatus. ${ }^{26}$ Thus, the unique presence on the arca of the episode of the Last Judgment with its significant inclusion of trumpets visually invokes the holy bishop as an intercessor during this crucial moment in the salvation of the souls of the departed. Naturally, everyone hoped for the intercession of the saints at the end of time; tellingly, however, the event was not represented on any other fourteenth-century saint's tomb. ${ }^{27}$ Concomitantly, the arca in the choir of the cathedral must have appeared to the faithful as a prospective symbol of the civitas Dei, which would, together with the Last Judgment, come about at the end of time. At its gates, the patron saint of Arezzo, Donatus, would intercede on behalf of the citizens of this commune.

The Arca di San Donato was erected after 1362, the same year in which the remains of the saint were rediscovered in the cathedral. Their discovery put an end to a long dispute over the 


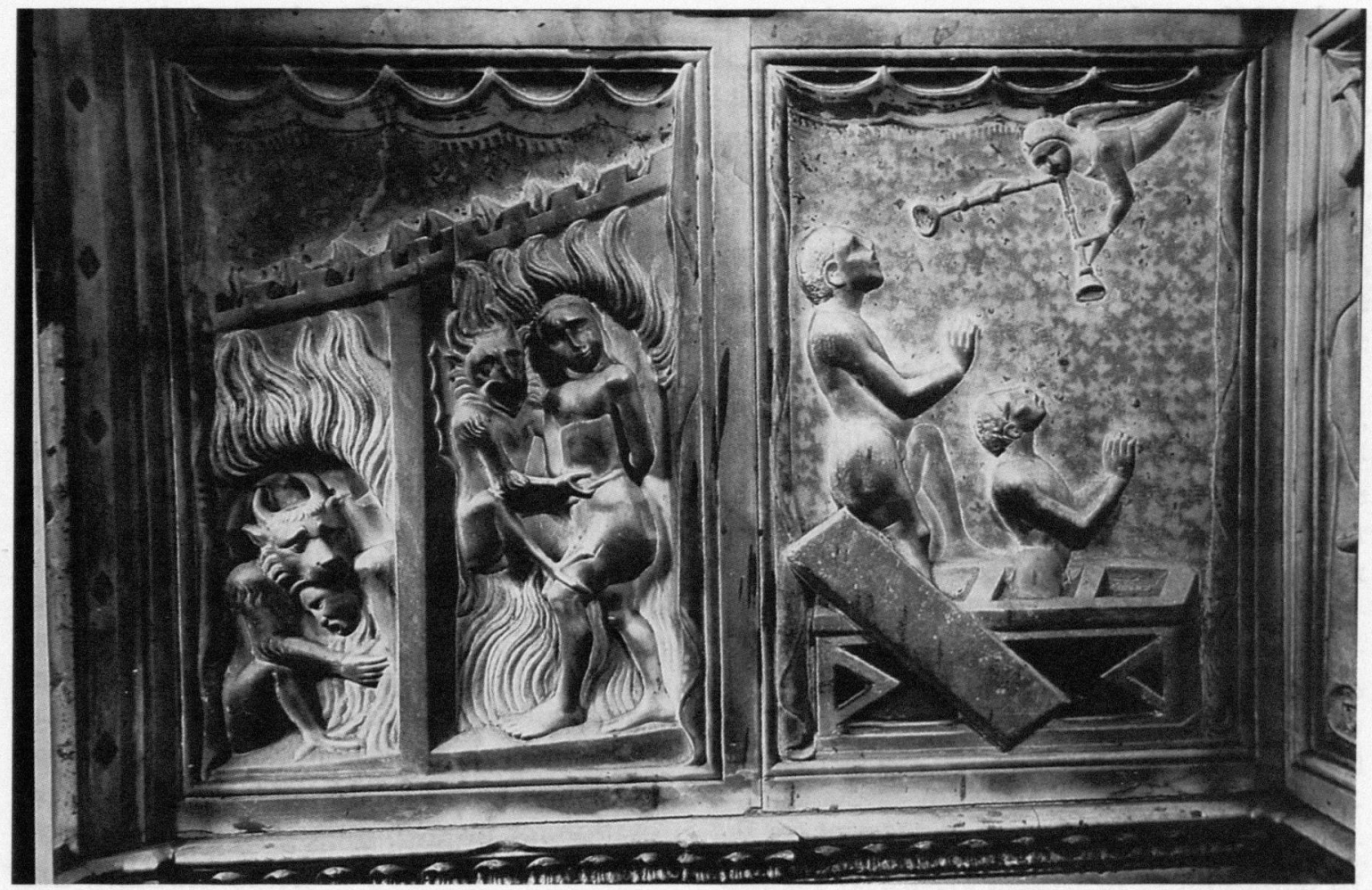

Fig. 7. Resurrection of Souls at the Last Judgment, detail of the Arca di San Donato, after 1362-c. 1375 (photo: Kunsthistorisches Institut in Florence)

saint's true burial place between the canons of the cathedral and the rival clerics of the Pieve, who had earlier defended their claim with the evidence of a head reliquary. ${ }^{28}$ Yet as the private contributions made by the populace demonstrate, the tomb did not originate simply as a result of an argument between competing clergymen. ${ }^{29}$ It was understood by both the city's inhabitants and by others to be an integral focal point of civic identity. This civic character of the shrine, moreover, was reinforced by the presence of yet another persona sancta. Sometime before 1327, the body of Gregory X, a sainted pope (d.1276), who rendered outstanding service in the rebuilding of Arezzo Cathedral, was provided with a tomb in the left chancel, on the opposite side of Tarlati's monument (figs 3, 8). ${ }^{30}$ Gregory X was first mentioned in 1327 in official documents as the cathedral's second patron saint. This multiplication of tombs reflects a larger phenomenon thoroughly discussed by André Vauchez: the striving of central Italian cities in the late Middle Ages to acquire and adopt additional, more recently deceased patrons as celestial advocates. ${ }^{31}$

The relics of the two patrons guaranteed the protection and the cohesion of the city. ${ }^{32}$ In the

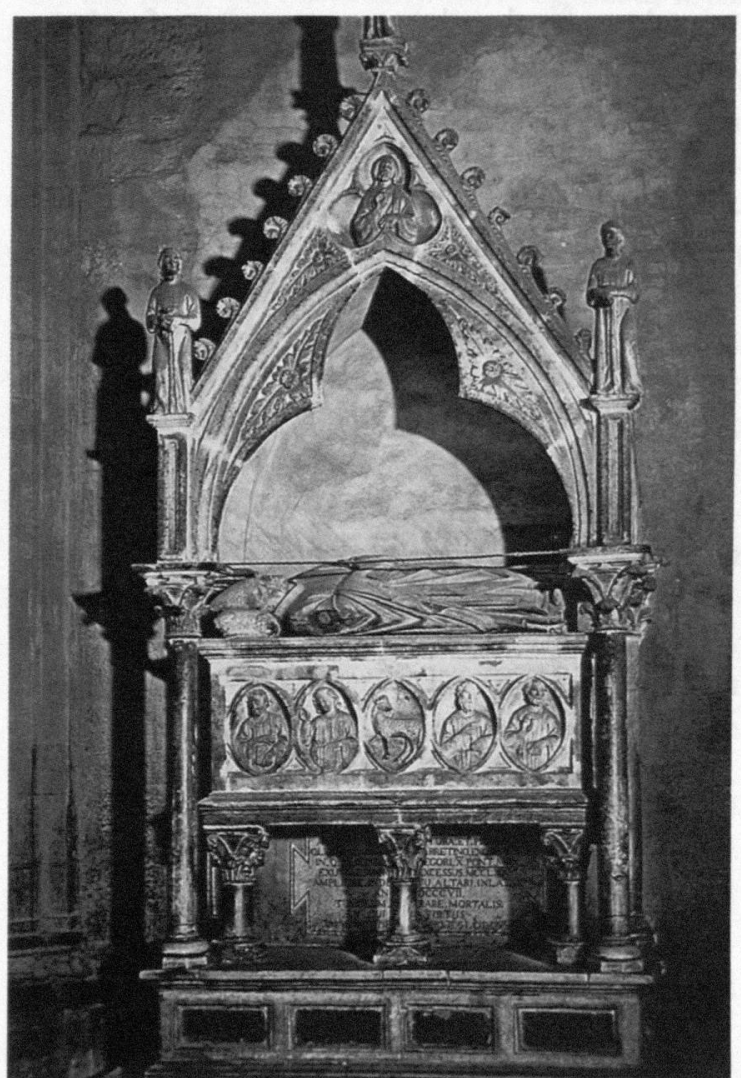

Fig. 8. Tomb of Pope Gregory X. Arezzo, cathedral, $c$. 1300-10 (photo: Kunsthistorisches Institut in Florence) 
early $1360 \mathrm{~s}$, as disputes between Guelphs and Ghibellines reached a new high point, and as Florence increasingly asserted its claims to political hegemony over Arezzo, this protection and civic unity were urgently needed. A few years earlier, radical Guelphs had chopped off the heads of all sixteen portrayals of the Ghibelline bishop Tarlati, and probably of his predecessors in the episcopate, on his tomb in the cathedral (the current heads are an eighteenth-century restoration). The new tomb of the city's patron would serve, in contrast to the vandalized monument, as a unifying symbol and an embodiment of civitas. During 1384-86, when Arezzo was in the midst of being plundered by foreign soldiers, it seemed to one contemporary that the final sign of indignity was the desecration of the relics of Saint Donatus. ${ }^{33}$

\section{The Crisis of the Saint's Tomb around 1400}

How might we now begin to account for the fact that, with the Arca di San Donato in central Italy and, analogously, with the tomb of Saint Augustine in north Italy, the building of monumental saints' tombs came to an almost abrupt end? The hybrid form of both of these saints' tombs already suggests a sort of exhaustion of possibilities. The strategies used in the Arca di San Donato of emulating recent precedents could no longer be escalated; the differences between sumptuous secular monuments and those for saints had become too blurred. Formal reasons alone, however, can hardly account for the whole phenomenon, which lasted half a century and which prevailed in all of north and central Italy. A number of additional factors must also be considered.

The crisis of the saint's tomb coincides with a crisis of the institution of the commune itself. In the late fourteenth and early fifteenth centuries, a number of smaller city-states lost their political independence, and early forms of territorial states took shape in their place. ${ }^{34}$ With the disappearance of civic autonomy, the need to erect publicly financed saints' tombs as foci for shared religious identity and protection apparently disappeared as well. Even when there was no apparent decrease in devotion or spending, resources were redirected towards other forms of veneration. ${ }^{35} \mathrm{It}$ is telling that the Ara di San Donato appeared during the last years of Arezzo's independence. It was built after the first, unsuccessful, attempt by Florence to con- quer the city, but before the city's final subjugation in 1384. The commune-crisis theory, of course, fails to explain why neither the large new centralized states, nor the religious orders unaffected by the new political and military developments, ceased to venerate their patrons with traditional monuments.

The conditions of the time, such as the economic collapse after the plague, political chaos, and the crisis of faith during the Great Schism, ${ }^{36}$ must also have been decisive, if only in some of the areas that manifest an interruption in the building of saints' tombs. This appears to have been the case, for example, in Rome, where new tombs only began to appear between 1430 and 1440 , as part of a general renovation of the city under Popes Martin V, Eugenius IV, and Nicolas $\mathrm{V}^{37}$ We might compare the spirit of this enterprise to that described in the preface to Antonio degli Agli's near contemporary Vitae gestaque sanctorum, which credits the popes' renovation for his own interest in collecting scattered saints' lives, the earliest surviving humanist undertaking of its kind. ${ }^{38}$

Surprisingly, the intense honour accorded to saints actually seems, on the whole, to have increased in the late fourteenth century. What differentiates this devotional intensity from that of other centuries, however, is that the official presentation of sanctity and the devotion of the masses parted ways. A mere six persons were canonized in the fourteenth century, and of those, none corresponded to the newly popular type of the ascetic-mystic layperson-what Richard Kieckhefer describes as the 'unquiet soul'. 39 Only with the acceptance of Catherine of Siena's sainthood would the official position of the Church change. Furthermore, the Church's critical viewpoint regarding ascetics and mystics was bolstered by such contemporary intellectuals as Giovanni Boccaccio and Franco Sacchetti, who sharply condemned, even mocked, some of the popular forms of attention paid to obscure, local saints. ${ }^{40}$ The ecclesiastical rejection of the popular saint-type and the even more strident criticism of these forms of devotion contributed to the same end: for the 'new local saints', no large, official tomb monuments were erected. Although, even in the first half of the fourteenth century, congregations had built tombs with hopes for the quick canonization of their occupants, and although popular religious movements continued to seek 'worthy resting places' for their 
holy heroes, demands for such honourable collocations were answered in the decades around 1400 only with altarpieces, frescoes, wooden shrines, and the like. ${ }^{41}$

Finally, religious aspirations of the period around 1400 were characterized by the search for an undiluted ecclesia primitiva, in an attempt to follow the examples of the apostles, the first Christian congregations, and the famous mystics of the High Middle Ages. ${ }^{42}$ In some respects, this pursuit conformed to the early humanists' 'rediscovery' of the church fathers, with their new interest in Early Christian monuments, and with the demand for a sancta rusticitas, or 'holy simplicity'. ${ }^{43}$ Given the ideal of an ecclesia primitiva, a postulate of simplicity, and an orientation towards Early Christianity, relatively modest shrine forms for sacred bones must have seemed far more fitting than the previously used and much more decorative sarcophagi, which, following the example of the Arca di San Domenico, vied with ancient pagan monuments and with each other.

This constellation of circumstances also helps to explain the exceptional situation in Florence, where, in the later Middle Ages, no single large monument for any saint's tomb seems to have been constructed. Only in 1409, with the advancement of the rebuilding of the cathedral, did Florentines respond to the monuments for civic saints that other Tuscan cities boasted, deciding then and there to build a marble tomb for Saint Zenobius in a chapel of the cathedral's apse. Not until 1428, moreover, were any specific plans underway for an altar and a bronze or marble shrine, on which the gisant of the saint was to be visible. Five years later, the entire original project was scrapped in favour of something wholly different, namely the bronze shrine for the head of the saint executed by Lorenzo Ghiberti and a reliquary-altar for the bones designed by Filippo Brunelleschi. ${ }^{44}$ Previously, Ghiberti had completed a similar shrine for Saints Proto, Hyacinth, and Nemesius-albeit, in this case, for their entire bodies. Of this, we know not only the format of its original setting, in a sort of arcosolium in the wall of the monks' choir, but also the name of its spiritus rector-the Camaldolese abbot Ambrogio Traversari, known for being one of the main protagonists of the "patristic revival'. ${ }^{45}$ The shrine form is not the only feature of these works to return to its presumably ancient models. The inscription, which designates the tomb as a loculus, also alludes explicitly to Late Antique and Early Christian funerary customs. Incidentally, the new arcosolium form of these tombs was immediately adapted for secular monuments, and the competitive endeavours refuelled once again the fabrication of ever more elaborate monuments. ${ }^{46}$

To sum up, in the late fourteenth century, with the competitive, aggressive building campaigns to construct saints' tombs, and with the appearance of ever more elaborate secular tomb-monuments, the formal possibilities that such escalation demanded reached their culmination. The attempt by cities and orders to promote their own saints and celestial protectors through lavishly decorated tombs had finally precipitated a 'crisis' in the decades around 1400. Neither the political decline of the communes nor their economic situations, and neither the restrictive politics of canonization by the Church nor the increasing criticism of popular forms of devotion, permitted the erection of elaborate monuments for the countless, but for the most part officially unrecognized, local saints. When holy bones were to be newly presented, communities turned, in accordance with the ideals of an ecclesia primitiva, to simpler forms. In the humanistic climate of early fifteenth-century Florence, it was ostensibly Early Christian models, such as the shrine in a loculus, that were revived.

In the second half of the fifteenth century, especially in northern Italy, the emulative impulse in saint's tombs began anew. Relics were once again buried in free-standing sarcophagi decorated with reliefs and columns. ${ }^{47}$ Additionally, as before, visual parallels were drawn between several contemporary sacred and secular tomb-monuments. ${ }^{48}$ Only after sweeping Church reforms in the middle of the sixteenth century does the horizon of expectations seem to have changed fundamentally. Only then, finally and exclusively, does the 'archaic form' of the arca raised upon supporting columnswhich thus seems both metaphorically and visibly to lift the meritorious body of the holy dead to heaven-denote an unmistakable sign of sainthood. ${ }^{49}$ 


\section{APPENDIX}

Monumental tombs (marble, bronze, or terracotta) of saints in northern and central Italy, c. 1267-1525

\begin{tabular}{|c|c|c|}
\hline TOMBS & LOCATION & DATE \\
\hline S. Agatha & Verona, Cathedral & 1353 \\
\hline B. Osanna Andreasi & formerly Mantua, S. Domenico & c. 1505 \\
\hline S. Aniello & Lucca, Cathedral & 1416 \\
\hline S. Ansovino & Camerino, Cathedral & c. $1390-1418$ \\
\hline S. Antonio & Padua, The Santo & $\begin{array}{l}1263,1310,1350 \\
1470,1500-34\end{array}$ \\
\hline SS. Apollonio and Filastio & Brescia, Duomo Nuovo & c. $1504-10$ \\
\hline S. Arealdo & Cremona, Cathedral & 1484 \\
\hline S. Atto & Pistoia, Cathedral & 1337 sqq. \\
\hline S. Agostino & Pavia, S. Pietro in Ciel d'Oro & c. $1355-$ c. 1383 \\
\hline SS. Avertano and Romeo & Lucca, Oratorio della Madonnina & $1480 \mathrm{~s}$ \\
\hline S. Bartolo & S. Gimignano, S. Agostino & $1317,1492-1500$ \\
\hline B. Benedetto XI & Perugia, S. Domenico & $1324 / 25$ \\
\hline B. Bernardino da Feltre & Pavia, S. Giacomo fuori le mura & 1496 \\
\hline S. Bernardino da Siena & L'Aquila, S. Bernardino & 1505 \\
\hline B. Bernardo degli Uberti & Parma, Cathedral & after $1439,1519-48$ \\
\hline B. Bertrando & Udine, Baptistery & c. $1340-50$ \\
\hline S. Boccardo & Berceto, S. Moderanno & 1355 \\
\hline B. Bovo & Voghera, S. Bovo & after 1469 \\
\hline SS. Quattuor Canziani & Aquileia, Cathedral & c. 1330 \\
\hline S. Catherina da Siena & Rome, S. Maria sopra Minerva & 1380,1430 \\
\hline S. Celestino & L'Aquila, S. Maria di Collemaggio & 1517 \\
\hline S. Cerbone & Massa Marittima, Cathedral & 1324 \\
\hline S. Colombano & Bobbio, Cathedral & 1480 \\
\hline S. Cristina & Bolsena, S. Cristina & c. 1495 \\
\hline S. Pietro Damiano & formerly Faenza, S. Maria fuori porta & 1354 \\
\hline S. Domenico & Bologna, S. Domenico & $1265-67,1469-73,1494,1532$ \\
\hline S. Donato & Arezzo, Cathedral & after 1362 \\
\hline S. Donnino & Fidenza, Cathedral & 1488 \\
\hline S. Emiliano & Faenza, Cathedral & c. 1462 \\
\hline B. Enrico da Bolzano & Treviso, Cathedral & $1316(?)$ \\
\hline S. Eutichio & Como, S. Giorgio in Borgonuovo & mid-fifteenth century \\
\hline S. Evasio & Casale Monferrato, Cathedral & c. 1525 \\
\hline S. Felice II & Padua, Santo & $1503 / 04$ \\
\hline B. Gabriele Ferretti & Ancona, S. Francesco ad Alto & 1489 (?) \\
\hline S. Fina & S. Gimignano, Collegiata & 1472 sqq. \\
\hline S. Geminiano & Modena, Cathedral & 1442 \\
\hline S. Giannelli & S. Ciriaco & c. 1509 \\
\hline B. Giovanni di Cagli & Cagli, S. Francesco & 1372 \\
\hline \multicolumn{3}{|l|}{ B. Giovanni da Fiesole } \\
\hline (Fra Angelico) & Rome, S. Maria sopra Minerva & late fifteenth century \\
\hline S. Girolamo & formerly Rome, S. Maria Maggiore & $1461-64$ \\
\hline S. Giustina & formerly Padua, S. Giustina & c. 1475 \\
\hline B. Gregorio X & Arezzo, Cathedral & early fourteenth century \\
\hline
\end{tabular}




\begin{tabular}{|c|c|c|}
\hline TOMBS & LOCATION & DATE \\
\hline S. Imerio & Cremona, Cathedral & $1479-82$ \\
\hline S. Isidoro & Venice, S. Marco & c. $1350-55$ \\
\hline S. Lanfranco & Pavia, S. Lanfranco & 1498 \\
\hline B. Luca Belludi & Padua, Santo & c. 1285,1382 \\
\hline S. Luca & Padua, S. Giustina & c. 1316 \\
\hline SS. Marcellino and Pietro & formerly Cremona, S. Tommaso & 1506 sqq. \\
\hline B. Marcolino & formerly Forli, S. Giacomo & 1458 \\
\hline B. Margherita da Cortona & Cortona, S. Margherita & c. 1320 \\
\hline B. Margherita di Lussemburgo & $\begin{array}{l}\text { formerly Genova, } \\
\text { S. Francesco di Castelletto }\end{array}$ & \\
\hline B. Michelina & $\begin{array}{l}\text { S. Francesco di Castelletto } \\
\text { Pesaro, S. Francesco }\end{array}$ & $\begin{array}{l}1313 \text { sqq. } \\
1356 / 59\end{array}$ \\
\hline S. Monica & $\begin{array}{l}\text { Pesaro, S. Francesco } \\
\text { Rome, S. Agostino }\end{array}$ & $\begin{array}{l}1356 / 59 \\
1455\end{array}$ \\
\hline S. Mustiola & $\begin{array}{l}\text { Rome, S. Agostino } \\
\text { Chiusi, Cathedral }\end{array}$ & $\begin{array}{l}1455 \\
1474\end{array}$ \\
\hline B. Nazzario & $\begin{array}{l}\text { Chiusi, Cathedral } \\
\text { Capodistria, Cathedral }\end{array}$ & $\begin{array}{l}1474 \\
\text { before } 1381\end{array}$ \\
\hline S. Nicola da Tolentino & $\begin{array}{l}\text { Capodistria, Cathedral } \\
\text { Tolentino, S. Nicola }\end{array}$ & $\begin{array}{l}\text { before } 1381 \\
1474\end{array}$ \\
\hline B. Oderico Mattiuzzi & & \\
\hline da Pordenone & Udine, S. Maria della Carmine & 1332 \\
\hline S. Ottaviano & formerly Volterra, Cathedral (?) & c. 1320,1522 \\
\hline B. Pacifico & Venice, S. Maria Gloriosa dei Frari & c. 1437 \\
\hline S. Pellegrino & S. Pellegrino in Alpe & c. $1474-84$ \\
\hline SS. Martiri Persiani & Cremona, Cathedral & $1478-84$ \\
\hline S. Pietro Martire & Milan, S. Eustorgio & 1339 \\
\hline B. Pier Pettinaio & formerly Siena, S. Francesco & 1289 sqq. \\
\hline B. Gioacchino Piccolomini & formerly Siena, S. Maria dei Servi & c. 1320 \\
\hline B. Lorenzo Pisano di Ripafratta & Pistoia, S. Domencio & $1457 / 58$ \\
\hline SS. Proto, Giacinto, and Nemesio & formerly Florence, S. Maria degli Angeli & $1425-28$ \\
\hline S. Ranieri & Pisa, Camposanto & c. $1300-06,1451-52$ \\
\hline S. Regolo & Lucca, S. Martino & c. 1485 \\
\hline S. Rocco & Venice, S. Rocco & $1516-24$ \\
\hline S. Romano & Lucca, S. Romano & c. 1490 \\
\hline S. Rufillo & formerly Forli, S. Giacomo & before 1362 \\
\hline B. Beatrice Rusca & Milan, S. Angelo & 1499 \\
\hline B. Giacomo Salomoni & $\begin{array}{l}\text { Milan, S. Angelo } \\
\text { formerly Forli, S. Giacomo }\end{array}$ & 1340 sqq. \\
\hline B. Ambrogio Sansedoni & formerly Siena, S. Domencio & 1287 sqq. \\
\hline S. Savino & Faenza, Cathedral & 1474 sqq. \\
\hline S. Sigismondo & Imola, S. Maria della Regola & $1372 / 75$ \\
\hline S. Silao & formerly Lucca, S. Giustina & late fifteenth century \\
\hline S. Simeon & Venice, S. Simeon Profeta & 1317 \\
\hline B. Simona dei Cantulli & Parma, Cathedral & c. 1476 \\
\hline SS. Simeone, Giuda, & & \\
\hline & Verona, S. Giovanni in Valle & $1395 / 96$ \\
\hline $\begin{array}{l}\text { S. Terenzio } \\
\text { S. Terenzo }\end{array}$ & formerly Faenza, S. Renzio & $1461 / 62$ \\
\hline $\begin{array}{l}\text { S. Terenzo } \\
\text { SS. Teonesto, Tabra, and Tabrata }\end{array}$ & S. Terenzo, S. Terenzo Monti & 1525 \\
\hline $\begin{array}{l}\text { SS. Teonesto, Tabra, and Tabrata } \\
\text { S. Tiziano }\end{array}$ & Treviso, Cathedral & $1485-1506$ \\
\hline $\begin{array}{l}\text { S. Tiziano } \\
\text { S. Venanzio }\end{array}$ & Brescia, SS. Cosma e Damiano & 1505 \\
\hline $\begin{array}{l}\text { S. Venanzio } \\
\text { S. Vittore }\end{array}$ & Camerino, S. Venanzio & c. 1400 \\
\hline $\begin{array}{l}\text { S. Vittore } \\
\text { SS. Quattuor Vergini }\end{array}$ & Volterra, now Museo d'Arte Sacra & c. 1325 \\
\hline $\begin{array}{l}\text { SS. Quattuor Vergini } \\
\text { B. Villana }\end{array}$ & Aquileia, Cathedral & 1330 \\
\hline B. Villana & Florence, S. Maria Novella & c. 1451 \\
\hline SS. Vittore and Corona & Feltre, Santuario di SS. Vittore e Corona & $1438-40$ \\
\hline S. Zenobio & formerly Florence, Cathedral & $1432-40$ \\
\hline Anonymous saint & Volterra, now Museo d'Arte Sacra & c. 1331 \\
\hline
\end{tabular}


This essay represents part of a larger project on 'Body and Image of the Saints in the Italian Renaissance'. I would like to thank Stephen Lamia and Elizabeth Valdez del Álamo for the invitation to Leeds, and Michael Cole for illuminating discussions and the translation.

1. See the encomium in Piattino Piatti, Epigrammi Elegiaeque (Milan: Alexander Minutianus, 1502), p. 52; on this, see Giovanni Agosti, 'Scrittori che parlano di artisti, tra Quattro e Cinquecento in Lombardia', in Quattro pezzi lombardi (per Maria Teresa Binaghi), ed. by Barbara Agosti at alia (Brescia: Edizioni L'Obliquo, 1998), pp. 39-93 (esp. pp. 62-65, n. 62).

2. After the death of Piatti in 1479 the arca for the 'Persian Martyrs' was completed by G. A. Amadeo; it was dismantled in the nineteenth century. See Marco Tanzi, 'Novità per l'Arca dei Martiri Persiani', Prospettiva, 63 (1991), 50-62; and idem, 'Piatti, Amadeo e l'Arca dei Martiri Persiani', in Giovanni Antonio Amadeo, ed. by Janice Shell and Liana Castelfranchi (Milan: Cisalpino, 1993), pp. 175-88.

3. Anita Fiderer Moskowitz, Nicola Pisano's Arca di San Domenico and its Legacy (University Park: Pennsylvania State University Press, 1994); Barbara W. Dodsworth, The Arca di San Domenico (New York: Peter Lang, 1995); Klaus Krüger, 'Selbstdarstellung im Konflikt. Zur Repräsentation der Bettelorden im Medium der Kunst', in Die Repräsentation der Gruppen, ed. by Otto G. Oexle and Andrea von HülsenEsch (Göttingen: Vandenhoeck \& Ruprecht, 1998), pp. 127-68; Randi Klebanoff, 'Sacred Magnificence: Civic Intervention and the Arca of San Domenico in Bologna', Renaissance Studies, 13 (1999), 412-29.

4. '[...] in forma et materia simile per omnia sepulcro beati Dominici, patris nostri [...]'; see Anita Fiderer Moskowitz, 'Giovanni di Balduccio's Arca di San Pietro Martire: Form and Function', Arte lombarda, 96-97 (1991), 7-18.

5. See the examples in Jörg Garms, 'Gräber von Heiligen und Seligen", in Skulptur und Grabmal des Spätmittelalters in Rom und Italien (Vienna: Österreichische Akademie der Wissenschaften, 1990), pp. 31-60.

6. Compare the Dominican bishop Bartolomeo di Vicenza's 'translation' sermon, 5 June 1267: 'De tertio benedicta est benedictione decoris, quod patet ex sculpturis et diversis caelaturis. Si enim Tyrannorum fortia gesta in arcubus, columnis et portis sculpebantur, eritura tamen, et plurimum nocitura, quanto magis mirabilia istius gesta et facta memorie filiorum utiliter et delectabiliter et salubriter commendanda in eternum victura?'. On this, see Andrea Franci, 'Le arche dei Santi: evoluzione e continuità nei monumenti sepolcrali di S. Domenico, S. Pietro Martire e S. Agostino', Arte Cristiana, 83 (1995), 157-60.

7. Giorgio Bejor, "Il reimpiego di sarcophagi antichi nell'Italia Longobarda', in Colloquio sul reimpiego di sarcophagi romani net Medioevo, ed. by Bernard Andreae and Salvatore Settis (Marburg: Verlag des Kunstgeschichtlichen Seminars, 1984), pp. 93-102.

8 . This is not to deny that, alongside this principal form, there were other types of tombs. One thinks, for instance, of the Sienese wall-tomb. See Garms, 'Gräber', passim; and idem, 'Arca', in Enciclopedia dell'arte medievale (Rome: Istituto della Enciclopedia Italiana, 1991-), II (1991), 259-62; Moskowitz, Nicola Pisano's Arca; Sarah Blake McHam, The Chapel of St.Anthony at the Santo and the Development of
Venetian Renaissance Sculpture (Cambridge: Cambridge University Press, 1994), pp. 85-89; Joanna Cannon and André Vauchez, Margherita of Cortona and the Lorenzetti (University Park: Pennsylvania State University Press, 1999), pp. 53-78.

9. These include the monuments for San Ansovino and San Venanzio, both in Camerino; for San Aniello in Lucca; for Santi Proto, Giacinto, and Nemesio in Florence; and the tomb for Santi Simeone, Giuda, and Saturnino in Verona (see Appendix).

10. See the examples in Sumptuosa tabula picta. Pittori a Lucca tra gotico e rinascimento, exh. cat., ed. by Maria T. Filieri (Livorno: Sillabe, 1998), pp. 242-44; see also the frescoed memorial for the blessed Angelo Mazzingi in Florence Cathedral.

11. The earliest ground plan of Arezzo Cathedral dates from 1760 . It was published by Marina Armandi, 'Vescovi e committenza, il caso della cattedrale aretina', in La battaglia di Campaldino: Atti del convegno (Arezzo 1989), pp. 234-57, esp. 242; and Stefano Casciu, 'Pianta della cattedrale', in Mater Christi:Altissime testimonianze del culto della Vergine nel territorio arretino, exh. cat., ed. by Anna M. Maetzke (Cinisello Balsamo: Silvana, 1996), p. 104.

12. Bibliotheca Sanctortum, IV, 773-82; see also Alain Boureau, 'Le Calice de Saint Donat. Legende, autorité et argeuil dans la controverse hussite (1414-1415)', Médiévales, 16-17 (1989), 209-15; Guglielmo Lützenkirchen, 'Il culto di San Donato di Arezzo nell'Italia centro-meridionale', Atti e memorie della Accademia Petrarca di Lettere, Arti e Scienze, 52 (1990), 33-47.

13. These two phases of development were first observed by Alessandro del Vita, L'altar maggiore del duomo di Arezzo (Milan: Alfieri \& Lacroix, 1911), pp. 7-9; and idem, Il duomo di Arezzo (Milan: Alfieri \& Lacroix, 1915), pp. 26-40. Del Vita, following Vasari, proposes that Giovanni Pisano was the 'ideatore' of the entire work. The best available overview of the relevant issues is that of Angelo Tafi, Arezzo, guida storico-artistica (Arezzo: Litostampa, 1978), pp. 238-40.

14. Originally, the opening must have been sealed with a grate or a door: compare the similar arrangements of the former high altar of the Florence Baptistry (early thirteenth. century) and of the altar of the Old Sacristy in San Lorenzo. In both of these examples, the opening was on the front side of the altar, apparently because the priest preached versus populum here. See Giovanni Poggi, 'L'antico altare del battistero fiorentino', Rivista d'arte, 7 (1910), 73-87.

15. Ersilia Agnolucci, 'L'arca-altare di San Donato nella cultura artistica del Trecento aretino', Antichità viva, 27 (1988), 32-38.

16. The most prominent examples are the now dismantled wall-tomb for Henry VII in the choir of Pisa Cathedral; the tomb for Robert the Wise in Santa Chiara, Naples; and the free-standing monument for Bernabò Visconti in San Bernardo in Conca, Milan, begun before 1363. For these, see, respectively, Volker Herzner, 'Herrscherbild oder Grabfigur? Die Statue eines Thronenden Kaisers und das Grabmal Heinrichs VII. von Tino di Camaino in Pisa', in Ikonographia, ed. by Bazon Brock and Achim Preiß (Munich: Klinkhardt \& Biermann, 1990), pp. 11-77; Johannes Tripps, 'Restauratio imperii: Tino di Camaino und das Monument Heinrichs VII. in Pisa', in Grabmäler der Luxemburger, ed. by 
Michael V. Schwarz (Luxemburg: CLUDEM, 1997), pp. 51-78; Lorenz Enderlein, Die Grablegen des Hauses Anjou in Unteritalien (Worms: Wernersche Verlagsgesellschaft, 1997); and Allison Lee Palmer, 'Bonino da Campione's Equestrian Monument of Bernabò Visconti and Popular Piety in the Late Middle Ages', Arte lombarda, 121 (1997), 57-67.

17. Christa Gardner von Teuffel, 'The Buttressed Altarpiece: A Forgotten Aspect of Tuscan Fourteenth Century Altarpiece Design', Jahrbuch der Berliner Museen, 21 (1979), 21-65.

18. Gert Kreytenberg, Orcagna's Tabernacle in Orsanmichele, Florence (New York: Harry N. Abrams, 1994).

19. Examples are found in Max Seidel, "Condizionamento iconografico e scelta semantica: Simone Martini e la tavola del Beato Agostino Novello', in Simone Martini, ed. by Luciano Bellosi (Florence: Centro Di, 1988), pp. 75-80; Marco Pierini, L'Arca di San Cerbone (Massa Marittima: Centro Studi Storici 'Agapito Gabrielli', 1995), p. 17. On panels with painted fronts and backs made for tomb-altars, see also Julian Gardner, 'Fronts and Backs: Setting and Structure', in his Patrons, Painters and Saints (Aldershot: Variorum, 1993), pp. 297-322.

20. Originally, each scene was labelled beneath with a metal inscription. Eleven of the inscriptions are known; following a theft in the nineteenth century, however, only one of the actual labels is left. The Donatus cycle begins beside the central triptych on the front of the altar in the lower register on the right. In all of the literature since Angiolo and Ubaldo Pasquini's La cattedrale aretina e i suoi monumenti (Arezzo: Ernesto Bellotti, 1880), pp. 51-65, the eleventh relief has been falsely identified as a 'Salvation of a Man Condemned to Death', and the subjects of the fourth and tenth scenes have been reversed. My captions to figs 4 and 5 indicate the correct subjects. In addition to a lectionary of the Archivio Capitolare in Arezzo, already cited by Pasquini, I have consulted the Golden Legend, a twelfth- or thirteenth-century passional in the Biblioteca Medicea Laurenziana in Florence (Plut. XX, cod.II, fols [148v-150r]) and Petrus de Natalibus, Catalogus Sanctorum et gestorum eorum (Vicenza: Enrico di Ca' Zeno, 1493), lib. VII, cap. xxxiii, fol. $\& 8$ r. No single text containing every scene shown here is known.

21. For the competition between the Augustinian eremites and both the Dominicans and the priests responsible for San Pietro, as well as for the competition between the cities of Pavia and Milan, see Max Seidel, 'Die Fresken des Ambrogio Lorenzetti in S. Agostino', Mitteilungen des kunsthistorischen Instituts in Florenz, 22 (1978), 185-252; and Anita Fiderer Moskowitz, 'A Tale of Two Cities: Pavia, Milan, and the Arca di Sant'Agostino', Source, 11 (1992), 1-9 (Moskowitz appears unfamiliar with Seidel's prior study).

22. On the Tarlati tomb, see Roberto Bartalini, 'Agostino di Giovanni e compagni. I. Una traccia per Agnolo di Ventura', Prospettiva, 61 (1991), 21-28; and, most recently, Georgina Pelham, "Reconstructing the Programme of the Tomb of Guido Tarlati, Bishop and Lord of Arezzo', in Ant, Politics, and Civic Religion in Central Italy, 1261-1352, ed. by Joanna Cannon and Beth Williamson (Ashgate: Aldershot, 2000), pp. 71-115; for observations about the dubious authenticity of the upper section and other passages, see Herzner, 'Herrscherbild oder Grabfigur', pp. 38-40. A comparable case is discussed in Jean-François Sonnay, 'Paix et Bon Gouvernment: à propos d'un monument funéraire du Trecento', Arte medievale, 2 ser., 4.2 (1990), 179-93.

23. Petrus Damianus, Sermo XXXVIII, 'De SS. Donati et Hilariano Martyribus', in Patrologia Latina, 144, cols
705-10; and 'De SS. Donato et Hilariano. Hymnus', in ibid., 145 , cols $954-56$. For the image of the Heavenly Jerusalem in the thirteenth and fourteenth centuries and its connection to real cities, see Chiara Frugoni, $A$ Distant City. Images of Urban Experience in the Medieval World (Princeton: Princeton University Press, 1991); Anna I. Galletti, 'Gerusalemme o la città desiderata', Mélanges de l'École Française de Rome, Moyen Age-Temps Modernes, 96 (1984), 459-87.

24. Petrus de Natalibus, Catalogus Sanctorum, fol. A2r, 'Prologus totius operis': 'Increata sapientia summi verbi [...] volens omnes homines salvos fieri: ut electas sanctorum animas vocaret ad arcem: \& ad superne menia civitatis: edificavit sibi domum ecclesie sacrosancte septem excisis columnis fundatam septemplici fundamento: videlicet septiformis gratie stabilitam: muris munitissimis: \& turribus altissimis circunseptam: non quidem sculptis lapidibus: aut manufactis lateribus erectis: sed sanctorum meritis invisibiliter fabrefactis $[\ldots]^{\prime}$.

25. See the slightly later description in Federico Frezzi, Il quadriregno, ed. by Enrico Filippini (Bari: Laterza, 1914), lib. IV, cap. $x V$, pp. 347f.: 'Paulo mi mise poi nel templo sacro, / fatto di sangue e fatto di fortezza / di santi, morti a duolo acerbo e acro. / Parea ch'andasse al cielo la sua altezza, / edificato in dodici colonne, / e quattro miglia o quasi nell'ampiezza: / [...] / Mai Policleto, né musaica arte, / neanco Giotto fe' cotal lavoro, / qual era quel di quelle menbra sparte / [...]'.

\section{Petrus Damianus, Sermo, col. $709 f$.}

27. A painted example can be found on a family tomb in the Bardio di Vernio Chapel in Santa Croce, Florence; the meaning of the elevatio scene on the Margharete tomb in Genoa is contested; see most recently Johannes Tripps, 'Eine Schutzheilige für Dynastie und Reich. Giovanni Pisano und das Grabmal der Margarete von Brabant in Genua', in Grabmäler der Luxemburger, pp. 27-49.

28. Daniela Galoppi Nappini, 'Nuovi contributi allo studio dell'oreficeria aretina trecentesca', Annali della Scuola Normale Superiore di Pisa, Classe di Lettere e Filosofia, 3 ser., 14.2 (1984), 581-601; Diana Webb, Patrons and Defenders. The Saints in the Italian City-States (London and New York: Tauris, 1996), pp. 66-68, 118, 222-24.

29. Arezzo, Archivio della Fraternità dei Laici, Libro dei Testamenti A, segn. 726, fol. 44r, Testament of Iacopo da Bibiena, 14 February 1362: 'Item reliquit operi episcopatus civitatis aretii ob Reverentiam pretiosi martiris sancti donati episcopi / cuius corpus [...] est reinventum in catecdalj (sic) ecclesia. Libras decem'.

30. The tomb was only transferred to the right side aisle of the church in 1810; see Gianna Bardotti Biasion, "11 monumento di Gregorio X ad Arezzo', in Skulptur und Grabmal, pp. $265-73$.

31. On civic patrons, see André Vauchez, 'Patronage des saints et religion civique dans $l^{\top}$ Italie communale à la fin du Moyen Age', in Patronage and Public in the Trecento, ed. by Vincent Moleta (Florence: Olschki, 1986), pp. 59-80; see also Alba M. Orselli, Limmaginario religioso della città medievale (Ravenna: Edizioni del Girasole, 1985); and Webb, Patrons and Defenders, passim.

32. The importance of the relics of a patron for the existence of a city was demonstrated in 1362 , when, following the destruction of Forlimpopoli, Albornoz transferred the bones of San Rufillo to Forlì and had a new tomb built for them. See Michele Maccarrone, "La traslazione di S. Rufillo nel 1362 e la sua arca in Forlì', Rivista per la storia della chiesa in Italia, 5 (1951), 358-71. 
33. Giovanni L. De Bonis, Liber inferni aretii, ed by Arturo Bini, Rerum Italicarum Scriptores, 15.1 (Bologna: Nicola Zanichelli, n.d.), p. 26 (this appeared well after 1386): 'Odi che fe" un crudel pattarino: / ruppe, du' sta, il co' di san Donato, / nè curò ch'esso fusse sacro o divino; / e l'ornamento ebbe dirobbato / e lassolli 'a cuca remonita: / el presul nostro e martire beato!'. On the historical situation in Arezzo in the second half of the fourteenth century (with further bibliography), see Augusto Antoniella, 'Affermazione e forme istitutionali della dominazione fiorentina sul territorio di Arezzo (secc. XIV-XVI)', Annali aretini, 1 (1993), 173-203.

34. Giorgio Chitrolini, La formazione dello stato regionale ele istituzioni del contado (Turin: Einaudi, 1979); Ovidio Capitani, 'Dal Comune alla Signoria', in Storia d'Italia, ed. by Giuseppe Galasso (Turin: UTET, 1979-84), IV (1981), $135-75$.

35. See the general observations in Daniel Arasse, "Ad perpetuam memoriam. Les nouvelles fonctions de l'image peinte en Italie: 1250-1400', Mélanges de l'École Française de Rome, Moyen Age-Temps Moderns, 100 (1988), 541-615; Samuel K. Cohn, Jr., The Cult of Remembrance and the Black Death (Baltimore and London: The Johns Hopkins University Press, 1992); Richard Goldthwaite, Wealth and the Demand for Art in Italy, $1300-1600$ (Baltimore and London: The Johns Hopkins University Press, 1993), esp. pp. 109-14.

36. Roberto Rusconi, L'attesa della fine: Crisi della societd, profezia, ed Apacalisse in Italia al tempo del grande scisma d'Octidente (1378-1417) (Rome: Istituto Storico Italiano per il Medioevo, 1979).

37. This was contemporary with the 1430 renovation of the second tomb for Catherine of Siena (originally erected 1380), as well as with the competition for the relics of Saint Monica; see Lidia Bianchi, 'Il sepolcro di S. Caterina da Siena", in Iconografia di S. Caterina da Siena, ed. by Lidia Bianchi and Diega Giunta (Rome: Città Nuova, 1988), pp. 15-62.

38. Antonio degli Agli, Vitae gestaque sanctorum, Biblioteca Apostolica Vaticana, Vat. lat. 3742, fol. [1v]; the vita of Saint Donatus is in lib. VIII, cap. ii, fols [143r-143v]; for the author and his work, see Diana M. Webb, 'Sanctity and History: Antonio degli Agli and Humanist Hagiography', in Florence and Italy. Renaissance Studies in Honour of Nicolai Rubinstein, ed. by Peter Denley and Caroline Elam (London: Westfield College, 1988), pp. 297-308.

39. Andre Vauchez, Sainthood in the Later Middle Ages, trans. by Jean Birrell, rev. edn (Cambridge: Cambridge University Press, 1997); Richard Kieckhefer, Unquiet Souls. Fourteenth-Century Saints and their Religious Milieu (Chicago and London: University of Chicago Press, 1984); Claudio Leonardi, 'Committenze agiografiche nel Trecento', in Patronage and Public, pp. 37-58.

40. Claudio Leonardi, 'Intellectuals and Hagiography in the Fourteenth Century', in Intellectuals and Writers in the Fourteenth Century, ed. by Piero Boitani and Anna Torti (Tübingen and Cambridge: Gunther Narr and D. S. Brewer, 1985), pp. 7-21; Emilio Pasqualini, 'La santità nella letteratura italiana del Trecento', in Santi e santità nel secolo XIV (Perugia: Università degli Studi, 1989), pp. 23-53.

41. See the examples in Aviad M. Kleinberg, 'Proving Sanctity: Selection and Authentication of Saints in the Later Middle Ages', Viator, 20 (1989), 183-205; Dominique Rigaux, 'Par la grâce du pinceau. Canonisation et image aux derniers siècles du Moyen Age', in Santità, culti, agiografia, ed. by Sofia Boesch Gajano (Rome: Viella, 1997), pp. 275-98; Letizia Pellegrini, 'Agiografia e santità dei Mendicanti: il caso di Nicola da Tolentino', in Agiografia $e$ culto dei santi nel Piceno, ed by Enrico Menestò (Spoleto: Centro Italiano di Studi sull Alto Medioevo, 1998), pp. $153-72$.

42. Giles Constable, 'Twelfh-Century Spirituality and the Late Middle Ages', Medieval and Renaissance Studies, 5 (1971), 27-60; Scott H. Hendrix, 'In Quest of the Vera Ecclesia: The Crisis of Late Medieval Ecclesiology", Viator, 7 (1976), 347-78; Mario Fois, 'L'Osservanza come espressione della Ecclesia sempre renovanda", in Problemi di storia della chiesa nei secoli XV-XVII (Naples: Edizioni Dehoniane, 1979), pp. 13-107.

43. Charles Stinger, Humanism and the Church Fathers: Ambrogio Traversari (1386-1439) and Christian Antiquity (Albany: State University of New York Press, 1977). Other artistic 'Christian Revivals' are hypothesized by Irving Lavin, Donatello's Bronze Pulpits in San Lorenzo and the Early Christian Revival, in his Past - Present (Berkeley: University of California Press, 1993), pp. 1-27; and Linda A. Koch, "The Early Christian Revival at S. Miniato al Monte: The Cardinal of Portugal Chapel', Ant Bulletin, 78 (1996), 527-55.

44. Richard Krautheimer and Trude Krautheimer, Lorenzo Ghiberti (Princeton: Princeton University Press 1956), pp. 141-43; Lorenzo Ghiberti, materia e ragionamenti, exh. cat. (Florence: Centro Di, 1978), pp. 412-16; Giovanni Monolli, "Gli "arredi" del Brunelleschi: gli altari', in Brunelleschiana, ed. by Franco Borsi et alia (Rome: Officina, 1979), pp. $182-92$.

45. Krautheimer, Lorenzo Ghiberti, pp. 138-42; Anna Benvenuti Papi, 'Un momento del Concilio di Firenze: La traslazione delle reliquie di San Zanobi', in Firenze e il Concilio del 1439, ed. by Paolo Viti (Florence: Olschki, 1994), I, 191-220; on the limits of Traversari's importance for the arts, see Georgia Clarke, 'Ambrogio Traversari: Artistic Adviser in Early Fifteenth-Century Florence?', Renaissance Studies, 11 (1997), 161-78.

46. This argument supports Howard Saalman's dating of the earliest surviving profane Renaissance arcosolium-tombs (for Onofrio Strozzi in the sacristy of Santa Trinità and for Maso degli Albizzi formerly in San Pier Maggiore) to the late 1420 s or 1430 s; see Saalman, 'Strozzi Tombs in the Sacristy of Santa Trinita', Münchner Jahrbuch der Bildenden Kunst, 3 ser, 38 (1987), 149-60; see also Andrew Butterfield, 'Social Structure and the Typology of Funerary Monuments in Early Renaissance Florence', Res, 26 (1994), 47-67; as well as the somewhat unconvincing hypothesis of Sally J. Cornelison, 'The Tomb of Giovanni di Bicci de'Medici', in The Sculpted Object 1400-1700, ed. by Stuart Currie and Peta Motture (Aldershot: Scolar Press, 1997), pp. 25-42.

47. Early examples are the tombs of San Arealdo, San Imero, San Donnino and the Santi Martiri Persiani; see Appendix.

48. See the examples in I monumenti Borromeo, ed. by Mauro Natale (Turin: Umberto Allemandi, 1996).

49. It was for this reason, for example, that the de' Lupi tomb in the oratory of San Giorgio in Padua was dismantled in 1592: people were mistakenly venerating the Stützentumba, with its baldachin, as a saint's tomb. See Mary D. Edwards, 'The Tomb of Raimondino de' Lupi and its Setting', The Rutgers Art Review, 3 (1982), 37-49. 